\title{
H1-B VISA PROGRAM REFORM: ANALYSIS OF A PROBLEM FACING POLICY DECISION MAKERS ON FOREIGN LABOR PRACTICES
}

\begin{abstract}
The immigration of foreign workers is a topic of utmost importance for the United States economy. To some extent, it should be considered as a matter of national priority. Over the past years, the number of foreign students that pursue a graduate degree at United States universities has increased, and keeps rising every year. The majority of these newly made doctorate students stay in the USA, in order to pursue specialty occupations. This paper will address issues regarding foreign immigration policies, and will contain a proposal to implement a system that can effectively and selectively deal with the increasing number of both foreign students and foreign workers who apply for work visas.
\end{abstract}

Key words: immigration, foreign labor, H1-B visa, specialty occupation, policy reform

\section{Introduction}

The percentage of doctoral degrees awarded to foreign students has risen from 11.3 to 24.4 between 1976 and $2000 .{ }^{1}$ More importantly, non-resident students have achieved a significantly higher share of degrees awarded in the physical sciences. That share was 36.5 percent in 2000, 50.7 percent being in engineering and 25.7 being in life sciences. ${ }^{2}$ Considering these numbers, it is a question whether the current immigration laws regarding foreign workers can effectively accommodate such a pool of talent. The $\mathrm{H}-1 \mathrm{~B}$ visa is a non-immigrant visa granted to foreign workers in specialty occupations by USCIS under the Immigration and Nationality Act. This visa is intended for specialty, highskilled foreign labor, such that allows U.S. employers to maintain employeremployee relationship with the beneficiary. In addition, the prospect's job must be classified as a specialty occupation, indicating that a bachelor's or master's

Jovan Gavrilović, B.A., Whitworth University, Spokane, WA, United States of America, e-mail: jgavrilovic16@my.whitworth.edu

$1 \quad$ Borjas, George J. (2005): “The Labor Market Impact of High-Skill Immigration”, NBER Working Paper No. 11217, 2-5.

2 Ibid., 3. 
degree is required as it suits the complexity of the job requirement. Over the past years, the H-1B cap has dropped from 195,000 to 65,000 in Fiscal Year of 2004. ${ }^{3}$ Furthermore, the American Competitiveness and Workforce Improvement Act of 1998 (ACWIA) introduced a fee that is required for employers to pay. Over the years, it was raised from $\$ 1,000$ to $\$ 1,500{ }^{4}$

In the first section of the paper I will focus on defining the problem and analyze the economic impact of foreign labor in the United States economy, primarily because, the immigration of skilled, specialty occupation foreign workers is of deep importance for the Unites States economy. In 2008, immigrants represented $16 \%$ of the U.S. workforce with a bachelor's education, accounting $29 \%$ of growth in this workforce during 1995-2008. ${ }^{5}$ Foreign workers represent a $24 \%$ share of occupations related to technology, innovation and commerce. The educational background of these workers is rather impressive. In 2014, 45\% of filed petitions for $\mathrm{H}-1 \mathrm{~B}$ were workers with a bachelor's degree, $43 \%$ with a master's degree and $8 \%$ had a doctorate. ${ }^{6}$ A majority of these petitions were computerrelated occupations totaling 203,425 positions versus 171,613 in $2013 .^{7}$

In the second part of the paper I will examine my proposed policy alternatives and what can be done to solve the problem. For instance, one approach would be to reduce the administrative cost of visa issuance. The employers would be incentivized to employ foreign workers with a fee less than $\$ 500$. Reducing the administrative costs would increase the petition pool, and add quality derived from the greater quantity of applicants. In addition, the USCIS should increase the $\mathrm{H}-1 \mathrm{~B}$ visa cap to a number greater than 85,000 . This will result in a greater employment of young, skilled immigrant workers and thus, a greater number of skilled workers by the firm. It is self-evident that the inclusion of foreign workers in the U.S. economy will enhance overall technology, generate growth and stimulate innovation. This is possible due to the foreign labor's positive impact on firms performances, demonstrated in various data tables and research papers. However, some individuals would be in conflict with this decision making process, as this will lead to labor saturation. As a result, there will be a reduction of job opportunities for the local population.

Last part contains in-depth proposals. That would constitute reducing the ACWIA employer fee from $\$ 1,500$ to $\$ 500$, and increasing the $\mathrm{H}-1 \mathrm{~B}$ visa cap to

Report on H-1B Petitions, http://www.uscis.gov/sites/default/files/USCIS/Resources/ Resources for Congress/FY_2014_H-1B_Petitions_Report_SIGNED.pdf (9. 4. 2015).

$4 \quad$ U.S. Department of Homeland Security, 2015.

$5 \quad$ Pekkala Kerr S. et.al.. (2014): Firms and the Economics of Skilled Immigration, Harvard Business School Working Paper No. 14-102, 23-27.

6 Characteristics of H-1B Specialty Occupation Workers, http://www.uscis.gov/sites/default/ files/USCIS/Resources/Reports and Studies/H-1B/h-1B-characteristics-report-14.pdf (9. 4. 2015).

U.S. Department of Homeland Security, 2015. 
150,000. In addition, a system of rankings and points should be implemented. Applicants will be ranked in accordance with specific criteria.

\section{H1-B Visa}

The $\mathrm{H}-1 \mathrm{~B}$ visa falls under the temporary immigration category, and is intended for foreign workers with a set of skills that are considered as "specialty skills". These individuals pursue specialty occupations that are defined as those requiring theoretical and practical application of specialized knowledge in areas like engineering, economics and medicine. These individuals usually come from an educated background, with majority of them having at least a bachelor's degree. $\mathrm{H}-1 \mathrm{~B}$ visa program allows employers to seek short-term help from these qualified foreign workers in the form of sponsorship. The process consists of several steps. The sponsoring company files the $\mathrm{H}-1 \mathrm{~B}$ application and specifies an individual candidate therein. This means that before the process begins, the prospective worker must reach an agreement with the company constituting an employeremployee match. However, various employers can simultaneously seek visas for the same prospective foreign worker, although due to the legal fees, employers send applications solely for international workers that committed to the issuing company. ${ }^{8}$ Prospective visa holders are essentially tied to their employer with little chance of portability and mobility. Upon successful completion of the $\mathrm{H}-1 \mathrm{~B}$ application, visa holders can enter the process of gaining permanent residency, also known as the green card. Employers can petition for permanent residence on behalf of the $\mathrm{H}-1 \mathrm{~B}$ worker. If the green card is not obtained, international workers and holders of $\mathrm{H}-1 \mathrm{~B}$ visas must leave the United States at the end of their respected visa period.

Initially adopted in 1990 through the Immigration Act, the annual cap on the number of $\mathrm{H}-1 \mathrm{~B}$ visas issued has fluctuated significantly. The annual cap refers only to issuances, excluding renewals for second and third-year terms. The numerical cap of 65,000 issuances, was reached for the first time in 1997 and later in 1998 due to the boom in the technology industry. ${ }^{9}$ In 1998, United States Congress enacted the American Competitiveness and Workforce Improvement Act (ACWIA) which lead to a temporary increase of $\mathrm{H}-1 \mathrm{~B}$ cap to 115,000 during 1999 and 2000. ACWIA imposed a fee for all employers, unless exempt under the law. As of 2001, they were required to pay $\$ 500$ for each foreign worker sponsored. The problem for foreign workers occurred, when the ACWIA fee was

$8 \quad$ Kerr R. William, Lincoln F. William (2010): “The Supply Side of Innovation: H-1B Visa Reforms and U.S. Ethnic Invention”, Journal of Labor Economics, University of Chicago Press, 473-508.

$9 \quad$ U.S Department of Homeland Security, 2015. 
raised by Congress to $\$ 1,000$. Legislation in 1998 and 2000 raised the cap to an all-time high of 195,000 visas. ${ }^{10}$ This move was justified by the statement that American companies were engaged with fierce competition in the global markets and were facing shortages of high-skilled, specialty labor. Although initially raised to 195,000 for 2001, 2002 and 2003, the H-1B issuance cap was reduced back to 65,000 per year, once the boom in the technology industry slowly diminished. ${ }^{11}$ To make matters worse, Congress adopted the H-1B Visa Reform Act of 2004 and made permanent changes to the ACWIA fee, raising it to $\$ 1,500$ per petition. ${ }^{12}$ Table 1 shows the number of $\mathrm{H}-1 \mathrm{~B}$ petitions that are filed and number of those petitions that are approved in the fiscal year of 2012, 2013 and 2014. Figure 1 shows the $\mathrm{H}-1 \mathrm{~B}$ visa issuances and its relation to population estimates.

\subsection{Economic Impact}

Before going into the economic impacts of foreign labor inclusion into the U.S. economy, I want to mention the impact on their immigration on high-skill labor markets. Empirical studies are based on the notion that shifts in the labor supply of refined-skill group will affect the earnings and employment opportunities within that group. Shifts in supply of foreign students pursuing doctorates, induced by immigration can identify the change in earnings of other doctorates. Analysis has shown that increases in the number of foreign students have a negative effect on the wages of competing domestic workers. ${ }^{13}$ To be more precise, studies have shown that a 10 percent increase in foreign doctorate students induced by immigration, causes a 3 percent reduction of earnings of competing domestic doctorates. ${ }^{14}$ Undoubtedly, these decisions had a lasting impact on the U.S. economy. Reducing the $\mathrm{H}-1 \mathrm{~B}$ cap by more than $50 \%$ is large enough to be economically relevant. Historically, the number of $\mathrm{H}-1 \mathrm{~B}$ visa holders grew exponentially in the late 1990s before reaching stagnation post 2000. Due to the recession in the technology industry, the employment opportunities for engineers and scientists weakened. However, even with the economic recovery shortly after, the reduced supply of H-1B visas altered growth. The Department of Labor (DOL) estimated over 1.8 million applicants and petitions for $\mathrm{H}-1 \mathrm{~B}$ visas during the 2001-2006 period only. ${ }^{15}$ These issues are affecting the U.S. economy, thus it is crucial for the USCIS and Congress to reconsider their policies on foreign labor and inclusion of skilled workforce into the U.S. economy.

\footnotetext{
10 U.S Department of Homeland Security, 2015.

$11 \quad$ Kerr R. William, Lincoln F. William, ibid., 480.

12 U.S Department of Homeland Security, 2015.

13 Borjas George J., ibid., 4.

14 Borjas George J., ibid., 5.

$15 \quad$ Kerr R. William. Lincoln F. William, ibid., 485.
} 
The $\mathrm{H}-1 \mathrm{~B}$ visa program played a significant role in terms of technology and innovation. Considering how important immigrants are for U.S. commerce and technology, the $\mathrm{H}-1 \mathrm{~B}$ visa program is a matter of critical policy significance. Conducting regression analysis using Ordinary Least Squares (OLS) estimation, it is found that there is a strong relationship between expansions in a firm's young skilled immigrant employment and expansions in other parts of the firm's skilled workforce. ${ }^{16}$ The term "young" refers to the H-1B workers under the age of 40 . The focus is on young workers, particularly because they account for the greatest portion of immigrants. In fact, $90 \%$ of $\mathrm{H}-1 \mathrm{~B}$ visa holders are under the age of 40 . Using the OLS estimation method, research shows that a $10 \%$ increase in a firm's young skilled immigrant employment results in a $6 \%$ increase in the total skilled workforce of the firm. ${ }^{17}$

For these reasons, it is illusory to think that maintaining H-1B cap of 65,000 will help in sustaining innovation and skilled labor force. Raising the H-1B cap by an additional 65,000 visas would increase U.S. science and engineering labor force by $1.2 \%$ under the notion of ceteris paribus. This constitutes a half of the median annual growth rate of science and engineering workers, at $2.7 \%{ }^{18}$ Consequently, the sheer size and number of SE foreign workers have the ability to drastically influence the growth of U.S. innovation. Furthermore, innovation growth has an impact on economic growth and total welfare in the long-term. Innovation growth can be calculated and perceived through patents issued by foreign workers per year. Figure 2 shows the patent trends, through ethnic shares of patents filed by inventors residing in the United States.

\section{Alternative Methods}

Considering the importance of this matter and its necessity for policy reform, many possible solutions can be found or created. Naturally, the first possible solution would be to have the $\mathrm{H}-1 \mathrm{~B}$ visa program unchanged, and therefore, the entire $\mathrm{H}-1 \mathrm{~B}$ visa holder population unaffected. Such a status quo has an advantage of being less costly, both in terms of legal fees and processing time. Considering the statistics, processing and approving 315,857 petitions requires a substantial amount of time and administration expenses. The duration of a regular processing period of an $\mathrm{H}-1 \mathrm{~B}$ visa is approximately two to six months. One could argue that another advantage of status quo policy would be that it allows domestic workers to gain specialization through advanced education and secure specialty occupation positions. Those mainly refer to domestic workers in the STEM fields. The U.S. government and private donors have created vari-

\footnotetext{
$16 \quad$ Pekkala Kerr S. et al., ibid., 25.

17 Ibidem

$18 \quad$ Kerr R. William, Lincoln F. William, ibid., 491.
} 
ous scholarship funds for high schools students pursuing a STEM major. The Department of Defense offers a huge incentive for STEM majors by covering a full-tuition and other education-related fees through its SMART Scholarship. Moreover, the National Society of High School Scholars Foundation (NSHSS) offers financial support to underrepresented groups who pursue STEM careers.

These efforts affirm that the U.S. Congress is trying to foster education in STEM fields, generate future SE workers and reduce the economy's dependence on skilled foreign labor. An obvious disadvantage of status quo policy is the fall in productivity, stagnation in innovation and lack of competitiveness of American firms. In today's modern business framework, global competitiveness and domination in global markets are key profit drivers. Skilled labor leads to innovation, innovation leads to growth, and growth leads to higher profits. Without the qualified, highly skilled foreign labor, companies will be forced to shift their operations overseas in pursuit of cheaper, yet skilled work force. With the "no change" policy, there will be a decrease in the overall level of competitiveness for domestic companies. In terms of global competitiveness, the United States is ranked third, behind Switzerland and Singapore. ${ }^{19}$ In terms of innovation, the United States is ranked fifth, behind Finland, Switzerland, Israel and Japan.

The second solution would be, to reduce the ACWIA fee back to $\$ 500$ and increase the H-1B visa cap. Currently, the visa cap is so small that it takes only approximately seven days for applications to reach the limit of 65,000. This is a sharp fall compared to the Fiscal Years of 2010, 2011, and 2012. The number of days it took the applications to reach the 65,000 limit for those years were 264,300 , and 235 respectively. ${ }^{20}$ This is a clear indicator that the visa cap should be raised by a large margin, in order to accommodate a greater pool of applicants. There has been some recent initiative of the Senate to expand $\mathrm{H}-1 \mathrm{~B}$ visa cap to 135,000 , from 65,000 . The higher limit would then be allowed to increase or decrease by as much as 10,000 visas annually, based on demand for them and government unemployment data. ${ }^{21}$

An advantage of this policy alternative is that, on such visas, people will be able to switch employers more easily, making it difficult for companies to give wages that are below the market-level amount. This policy alternative would prevent the abuse of workers, by imposing higher fees and other restrictions on employers who have a large number of foreign workers on $\mathrm{H}-1 \mathrm{~B}$ visas. ${ }^{22}$ It would

19 The Global Competitiveness Report 2014 - 2015, http://www.weforum.org/reports/globalcompetitiveness-report-2014-2015 (15. 4. 2015).

20 Jordan M.: “Demand for Skilled-Worker Visas Exceeds Annual Supply“, http://www.wsj.com/ articles/u-s-demand-for-skilled-worker-visas-exceeds-annual-supply-1428431798 ( 8. 4. 2015).

${ }^{21}$ Visa Reforms for Skilled Workers, http://www.nytimes.com/2013/04/22/opinion/visareforms-for-skilled-workers.html?_r=1 (8. 4. 2015).

22 Meckler L.: "Bipartisan Senate Bills Would Increase Visas and Green Cards for High-Tech Workers", http://www.wsj.com/articles/bipartisan-senate-bills-would-increase-visas-andgreen-cards-for-high-tech-workers-1421191748 ( 8. 4. 2015). 
also change the perception of the U.S. job market as being more hospitable to skilled, foreign labor, making it inherently more attractive. A potential disadvantage of this policy alternative would be that adopting the bipartisan bills in the Senate, will lead to a concern that the new workers will provide unhealthy competition for American workers, who appear to be struggling. In order to persuade the Congress to oppose this immigration bill, Senator Jeff Sessions said that, there is already a shortage of qualified Americans, and a large number of them are unable to find employment. ${ }^{23}$ However, a commission chaired by former U.S. Secretaries of Labor Ray Marshall and William E. Brock has recently published a report about the predicament of the U.S. work force. According to the report, education and training of workers are falling behind. It is estimated that employers spend thirty billion dollars on formal training for workers, with one-third being allocated to frontline workers, and only eight percent of them benefit from it. Furthermore, roughly 15,000 firms account for nine-tenths of business spending on training, and fewer than 200 firms spend in excess of 2 percent of their payroll for this purpose. ${ }^{24}$

Another policy option, an alternative to the previous two, would be to adopt a merit-based visa system. This system is currently functioning in Canada, a country that has a good reputation for welcoming foreign skilled labor. In the United States, this system would allow issuance of H-1B working visas, based on a complete assessment of an individual's position-related skills, educational background, and employment history. Other factors such as cultural ties to the United States, knowledge of the English language, business activities, community service, and country of nationality will be taken into consideration as well. An advantage of this system is one that allows a better understanding of visa applicants, and a more thorough assessment of their qualifications and susceptibility to life in the United States. For instance, this system would begin with $100,000 \mathrm{H}-1 \mathrm{~B}$ visas and depending on the demand, grow even further. A potential disadvantage of this policy alternative would be, that given the selection criteria, this system might exhibit biasedness. For instance, a STEM visa applicant and a potential employee in the technology industry may have little-to-no English language proficiency, yet have superior job-related skills.

\subsection{Rationale}

When approaching this policy matter, it is important to establish the right ideological standpoint. However, it is important to note that no standpoint has been ever completely free of intellectual or practical problems. Experience taught

23 Preston J.: „Sessions Says Immigration Bill Is a Threat to U.S. Workers“, http://thecaucus.blogs. nytimes.com/2013/05/03/sessions-says-immigration-bill-is-a-threat-to-u-s-workers/ (9. 4. 2015).

24 America's Choice: High Skills or Low Wages”, The Free Library, http://www.thefreelibrary. com/America\%27s+Choice\%3a+High+Skills+or+Low+Wages.-a09232682 (9. 4. 2015).

Vol. 12, No 3, 2015: 277-290 
us that greater inclusion of foreign skilled-labor has a positive impact on technology, and thus, innovation. These experiences are documented in various scientific studies, therefore representing quantifiable and measurable claims. Hence, this is a highly attractive and effective proposal for policy affairs. Furthermore, the lacks of immigration policy initiatives, especially those dealing with foreign workers helps and improve my position. This is because my rationale offers visible ramifications and prompt answers to problems. As noted earlier, according to the opposing opinion on foreign labor, immigration is contagiously impassioned, and may seem patriotic. Their arguments can be deeply moving and appear as powerful motivators against the presence of skilled foreign workers into the U.S. economy. Their negative stance on foreign immigration is justified by the argument that it will dissuade the American workers from pursuing specialty occupations and education in STEM fields. Furthermore, it will lead to a cultural dispersion in a nation that is already culturally diverse. It is clear that their reasoning is a powerful in the political sphere due to its inability to lack testable proof or general disagreement.

\section{Proposed Method}

I recommend adopting the merit-based visa applications. This system will be a great change to the existing immigration system that is utilized in the United States. The implementation of this system is a rather straight-forward process. The merit-based system would set up two tiers, comprised of high-skilled workers in the first, and medium to low-skilled foreign workers. The visa issuance would be distributed 50\% to high-skilled workers and 50\% medium to low-skilled workers. ${ }^{25}$ Tier 1 bracket is designated for extensive preparation and specialization, and Tier 2 bracket accommodates professions that require medium to low expertise and less specialization. In addition, the ACWIA fee for $\mathrm{H}-1 \mathrm{~B}$ visa petitions would be reduced to $\$ 500$. This merit-based system would also incorporate points, that applicants accrue based on educational background, employment history/work experience, and other attributes. The maximum amount of points totals one-hundred. In order to have clarity in my proposal, I will first describe and analyze Tier 1 , and then Tier 2 .

When education is concerned, 15 points are assigned to applicants with a doctoral degree, 10 to master's degree holders, and 5 to bachelor's degree holders (Immigration Policy Center, 2013). In terms of work experience, an applicant can receive 3 points per year if he or she was legally employed in the United States in a Job Zone 5 occupation. If the applicant has been employed in a Job

25 The Border Security: "Economic Opportunity, and Immigration Modernization Act", http://immigrationpolicy.org/special-reports/guide-hr-15-border-security-economicopportunity-and-immigration-modernization-act (9.4. 2015). 
Zone 4 occupation, he or she can earn 2 points annually. Hence, a total of twenty points can be earned via employment. Job Zone 5 comprises jobs that require specialty, extensive preparation. This means that degrees such as Doctorate, Master's, Medical, or Professional are needed. These would be occupations such as: Surgeons, Biologists, Biochemists, Biophysicists, Dentists, Anthropologists, Neurologists, Mathematicians, Astronomers, Family and General Practitioners, Physicists, and Sociologists. Job Zone 4 comprises of jobs for which a considerable preparation is needed. In most cases, a Bachelor's degree is the minimum level of education. Examples of Job Zone 4 occupations include: Biochemical Engineers, Computer Programmers, Chemists, Civil Engineers, Software Developers, Accountants, and Electrical Engineers. If the visa applicant is already employed in the United States or already has an offer of employment in the United States that is related to his or her education, the applicant will receive 10 points for Job Zone 5 and 8 points for Job Zone 4 . This proposed visa program is designed to stimulate entrepreneurship, as a boost to the United States economy. Therefore, if the applicant is an entrepreneur having at least 2 employees in either Job Zone 4 or Job Zone 5, he or she will automatically receive 10 points. Despite specific job zones, and occupation classification, there are special rules that apply to applicants who belong to high-demand jobs. In such cases, if the applicant is employed in the United States or with offer of employment in the United States in high demand jobs, he or she will receive 10 points. Special cases like these are excluded from the general employment points that are based on years of employment. High demand occupations are those that are most highly petitioned for. This visa program also takes into account the applicants community service and civic engagement background. If the applicant has an experience in community service, he or she can receive up to 2 points.

Furthermore, applicants who have a good knowledge of English language receive special consideration. This is measured with a standardized, comprehensive English language exam. For instance, TOEFL would be a suitable testing tool. Should an applicant score equal to, or greater than 80 , he or she will receive 10 points. In order to improve the workforce demographics, age will be taken into the consideration. The reasoning is simple; the longer applicants can remain in the workforce, the more they will contribute. Therefore, applicants of ages between 18 and 24 years will receive 8 points. Those between 25 and 32 years will receive 6 points. Four points will be awarded to applicants aged between 33 and 37. Lastly, diversity and country of origin will be given a certain amount of consideration. For instance, applicants that are from a country that is underrepresented in the United States would receive 5 points. This would be determined from the number of foreign workers that have been working in the United States from that country in the last 5 years. If that number is less than 50,000 the country is considered as "underrepresented". 
As mentioned earlier in the paper, Tier 2 includes professions that require medium to low expertise and less specialization. For this group, a similar system would be adopted. There would be a maximum of 100 possible points, based on similar criteria with some slight changes. In terms of work experience, if the applicant has been legitimately employed in the United States, he or she may earn 4 points. The maximum amount of points that can be earned based on years of work experience is twenty. Those who have more than 10 years of employment in the United States will not proceed to accrue points anymore. If the applicant is qualified for a high demand occupation, and has an offer for full-time employment in the United States, he or she will receive 10. Also, there are 3 additional Job Zones; Job Zone 3, Job Zone 2, and Job Zones 1. Job Zone 3 entails those occupations for which medium preparation is required. This includes education, such as vocational school, or an associate's degree. Examples are: Dental Hygienists, Chemical Technicians, File Clerks, or Physician Assistants. Job Zone 2 includes jobs for which a certain level of preparation is necessary. Usually, this means that a high school diploma is required. Examples would be: Butchers, Telemarketers, Insurance Claims Clerks, Cooks, and Data Entry Workers. Job Zone 1 occupations are those where little or no preparation is required. Education wise, this means that only a high school diploma is necessary. Examples include: Fast Food Cooks, Farmworkers, Dishwashers, Janitors, Meat Packers, Waitresses, and Cashiers. Similarly to Tier 1, Tier 2 takes civic engagement into consideration. Applicants with significant amounts of community service may receive up to 2 points. In the same manner, English language proficiency is another key component of applicant's suitability assessment. Applicants who score over 80 in TOEFL will receive 10 points. Those applicants whose test result are in the range of 65 to 80 would receive 5 points. Once again, preference will be given to young applicants. Those applicants between the ages of 18 and 24 years will receive 8 points. Applicants between the ages of 25 and 32 years will receive 6 points. Applicants aged from 33 to 37 years will receive 4 points. Applicants from underrepresented countries of origin will automatically receive 5 points.

\section{Conclusion}

A country like the United States of America needs a merit-based visa system. In addition to the increased level of selectivity based on the previous premises, the cap would be raised from 65,000 to 120,000 . What is more important, applicants who are deemed as "highly qualified" but not meeting the criteria of other employment-based immigrant visa categories would be able to immigrate to the United States thanks to the points earned based on their attributes. In today's modern business framework, innovation and competitiveness play a cru- 
cial role, thus policy reforms are a matter of national priority. This issue is one that needs to be dealt with utmost knowledge, expertise and support from the political body, in order to reach a solution that would enhance the U.S. economy, stimulate growth and promote social equity.

\section{Literature}

- "America’s Choice: High Skills or Low Wages", The Free Library, http:// www.thefreelibrary.com/America\%27s+Choice\%3a+High+Skills+or+Low+Wages.a09232682 (9. 4. 2015).

- Borjas George J. (2005): "The Labor Market Impact of High-Skill Immigration", NBER Working Paper No. 11217

- Characteristics of H-1B Specialty Occupation Workers, http://www.uscis. gov/sites/default/files/USCIS/Resources/Reports and Studies/H-1B/h-1B-characteristics-report-14.pdf (09.04.2015).

- Jordan M.: "Demand for Skilled-Worker Visas Exceeds Annual Supply", http://www.wsj.com/articles/u-s-demand-for-skilled-worker-visas-exceeds-annualsupply-1428431798 (8. 4. 2015).

- Kerr R. William, Lincoln F. William (2010): "The Supply Side of Innovation: H-1B Visa Reforms and U.S. Ethnic Invention", Journal of Labor Economics, University of Chicago Press, 473-508

- Meckler L.: "Bipartisan Senate Bills Would Increase Visas and Green Cards for High-Tech Workers", http://www.wsj.com/articles/bipartisan-senate-billswould-increase-visas-and-green-cards-for-high-tech-workers-1421191748 (8 . 4. 2015).

- Pekkala Kerr S. et al. (2014): "Firms and the Economics of Skilled Immigration", Harvard Business School Working Paper No. 14-102

- Preston J.: "Sessions Says Immigration Bill Is a Threat to U.S. Workers", http://thecaucus.blogs.nytimes.com/2013/05/03/sessions-says-immigration-bill-is-athreat-to-u-s-workers/ (9. 4. 2015)

- Report on H-1B Petitions, http://www.uscis.gov/sites/default/files/USCIS/ Resources/Resources for Congress/FY_2014_H-1B_Petitions_Report_SIGNED.pdf (9. 4. 2015).

- The Border Security: "Economic Opportunity, and Immigration Modernization Act", http://immigrationpolicy.org/special-reports/guide-hr-15-border-security-economic-opportunity-and-immigration-modernization-act (9. 4. 2015)

- The Global Competitiveness Report 2014 - 2015, http://www.weforum. org/reports/global-competitiveness-report-2014-2015 (15. 4. 2015)

- Visa Reforms for Skilled Workers, http://www.nytimes.com/2013/04/22/opinion/visa-reforms-for-skilled-workers.html?_r=1 (8.4. 2015) 


\section{Appendix}

Table 1: Number of H-1B Petitions Filed and Number Approved

\begin{tabular}{|c|c|c|c|c|c|c|}
\hline & Fiscal Year & Oct to Dec & Jan to Mar & Apr to Jun & Jul to Sep & Total \\
\hline \multirow{3}{*}{ Petitions Filed } & 2012 & 65,186 & 36,217 & 150,104 & 56,206 & 307,713 \\
\cline { 2 - 7 } & 2013 & 40,048 & 39,433 & 159,380 & 60,606 & 299,467 \\
\cline { 2 - 7 } & 2014 & 45,211 & 42,781 & 158,623 & 72,209 & 318,824 \\
\hline \multirow{3}{*}{ Petitions Approved } & 2012 & 56,044 & 57,355 & 70,946 & 78,224 & 262,569 \\
\cline { 2 - 7 } & 2013 & 76,720 & 52,859 & 79,813 & 77,381 & 286,773 \\
\cline { 2 - 7 } & 2014 & 64,526 & 58,121 & 91,779 & 101,431 & 315,857 \\
\hline
\end{tabular}

Source: U.S. Department of Homeland Security

Figure 1: $H-1 B$ visas and Population Estimates

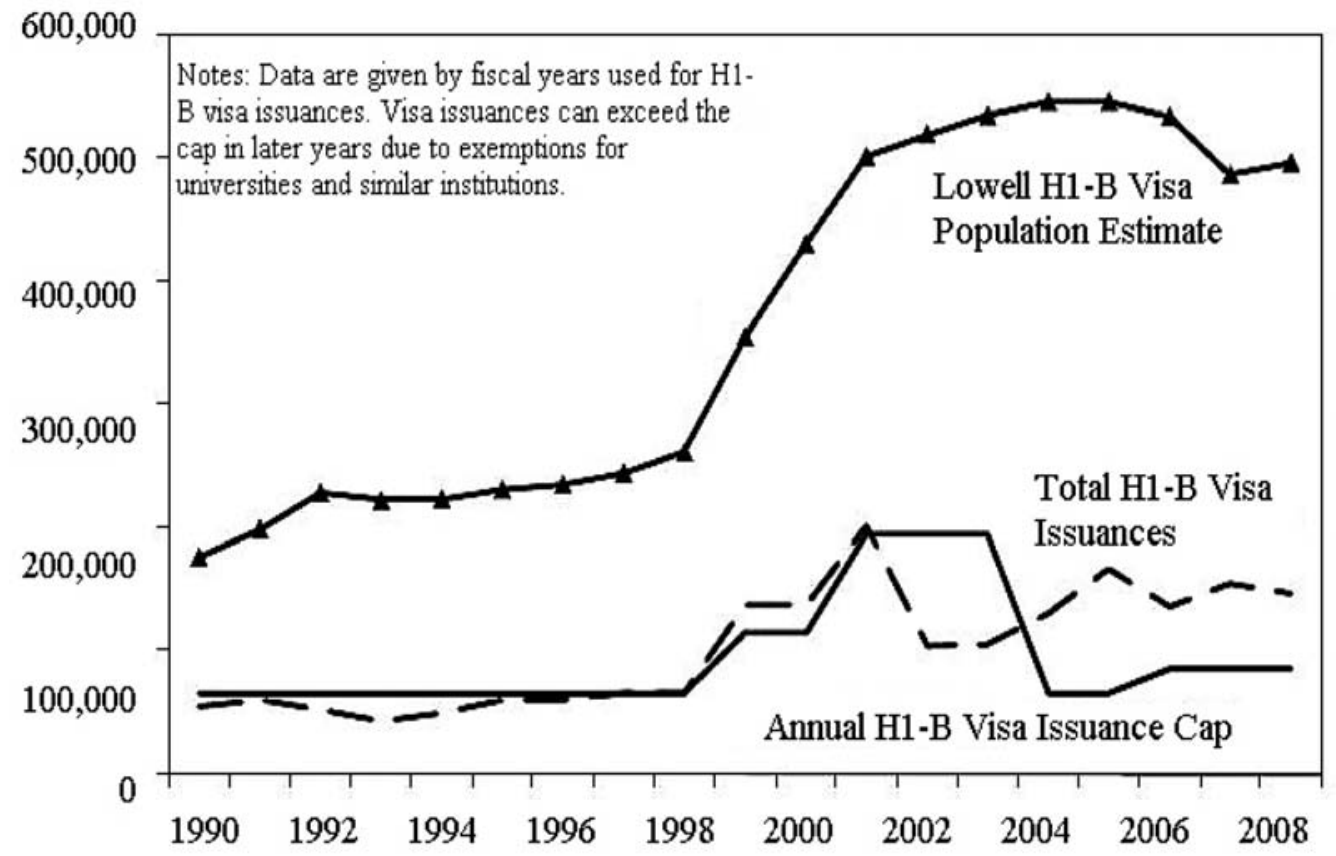


Figure 2: Growth in U.S. Ethnic Patenting (\% of U.S. patents)

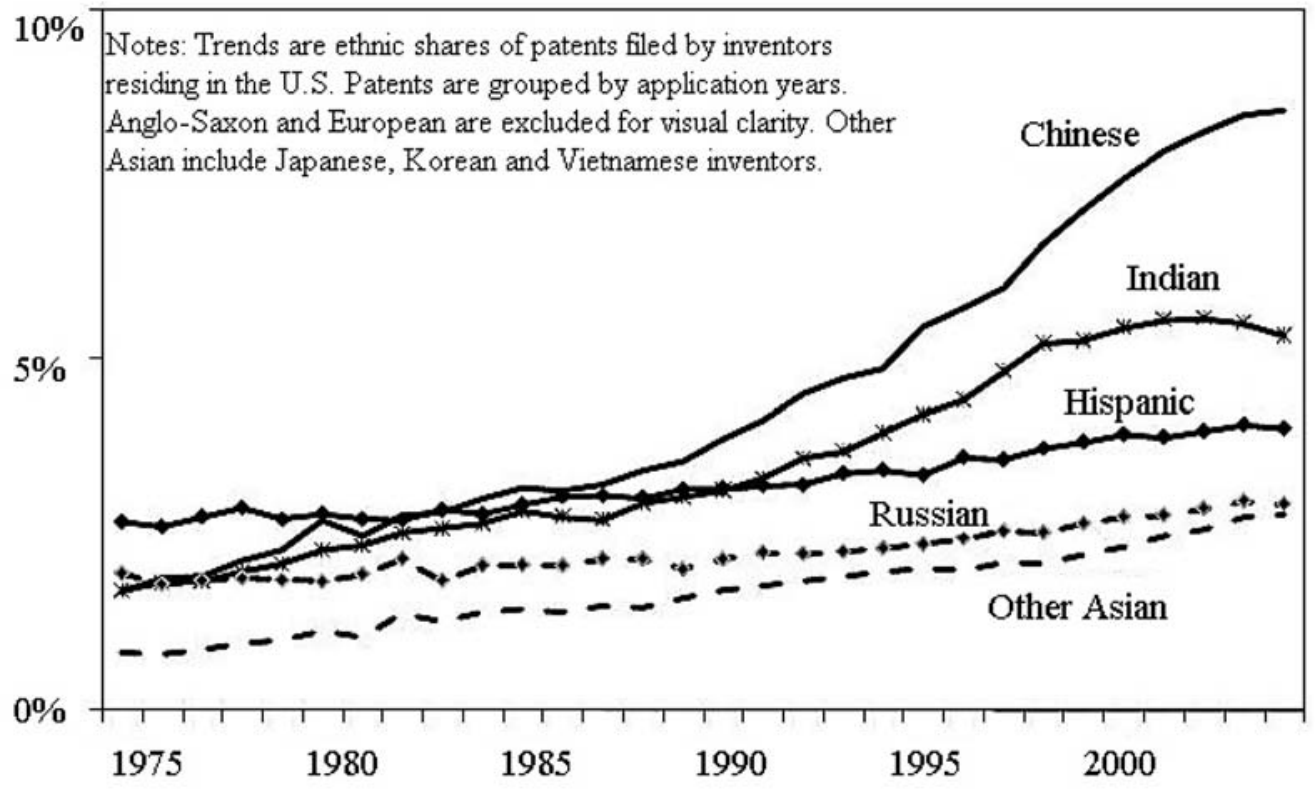

Source: Journal of Labor Economics

Rad primljen 1. oktobar 2015.

Odobren za štampu: 7. oktobar 2015.
Paper received: October $1^{\text {st }}, 2015$ Approved for publication: October $7^{\text {th }}, 2015$ 
Whitworth University, Spokane, Washington, U.S.A.

\section{REFORMA VIZNOG PROGRAMA H1-B: ANALIZA PROBLEMA DONOSILACA ODLUKA O SPECIJALIZOVANIM INOSTRANIM KADROVIMA}

\section{S a ž e t a k}

Imigracija inostranih kadrova je tema od izuzetnog značaja za ekonomiju SAD. U izvesnoj meri, ovaj problem treba posmatrati kao stvar nacionalnog prioriteta. Tokom proteklih godina broj inostranih studenata koji diplomiraju na univerzitetima u SAD se povećao i konstantno raste svake godine. Većina ovih studenata idu na doktorske studije radi ostvarivanja specijalizacije. Ovaj rad će se baviti pitanjima koja se tiču problematike imigracionog sistema i sadrži predlog za implementaciju platforme koja može efikasno i selektivno povećati broj inostranih kadrova u cilju poboljšanja i modernizacije ekonomije SAD.

Ključne reči: imigracija, inostrani kadar, H1-B viza, specijalizovano zanimanje, reforma 